\title{
KONSERVASI KUPU-KUPU SEBAGAI SERANGGA PENYERBUK YANG PENTING DI TAMAN NASIONAL BANTIMURUNG- BULUSARAUNG
}

\section{(Butterfly Conservation as Important Pollinator at Bantimurung-Bulusaraung National Park)}

\author{
Sri Nur Aminah Ngatimin ${ }^{1}$, Tamrin Abdullah ${ }^{2}$, Andi Nasruddin ${ }^{3}$, Fatahuddin ${ }^{4}$ \\ Staf Pengajar Departemen Hama dan Penyakit Tumbuhan, Fakultas Pertanian \\ Universitas Hasanuddin Jl. Perintis Kemerdekaan km. 10 Makassar 90245 \\ Email : srifirnas@gmail.com
}

\begin{abstract}
The purpose of study is to identify the species and frequency of butterfly visited on three types of flowers namely: Ixora paludosa, Hibiscus rosa-chinensis and Clerodendron japonicum. The information is very useful in the conservation effort of pollinator insects, especially butterflies that live around the Bantimurung-Bulusaraung National Park, Maros district, South Sulawesi, Indonesia. Research activities in the field trials were located in Simbang village (5 ${ }^{\circ} 01^{\prime} 23.2$ "S and 119 '40'33.6" E), Maros district, South Sulawesi. The research was conducted in August to September 2018. There were two families butterflies visited the flowers i.e: Pieridae and Papilionidae. Six species of butterflies visited I. paludosa flowers, four species visited H. rosa chinensis and seven species visited $C$. japonicum. The dominant butterfly species visited I. paludosa : Graphium agamemnon and Catopsilia scylla. The species of butterflies in $H$. rosa-chinensis are Papilio demolion and Troides helena, while those who frequently visited $C$. japonicum flower: $C$. pomona and C. scylla
\end{abstract}

Key words : butterfly, nectar, insect pollinator, Bantimurung, Sulawesi

\begin{abstract}
Abstrak
Tujuan penelitian adalah : mengidentifikasi spesies dan frekuensi kunjungan kupu-kupu pada tiga jenis bunga yakni : asoka (Ixora paludosa), kembang sepatu (Hibiscus rosa-chinensis) dan kembang pagoda (Clerodendron japonicum). Informasi ini sangat berguna dalam konservasi serangga penyerbuk khususnya kupu-kupu yang bermukim di sekitar Taman Nasional Bantimurung-Bulusaraung Kabupaten Maros, Sulawesi Selatan. Kegiatan penelitian berupa percobaan lapangan bertempat di Desa Simbang (501'23.2"S dan 11940'33.6"E) Kecamatan Bantimurung Kabupaten Maros, Sulawesi Selatan dilaksanakan pada bulan Agustus sampai dengan September 2018. Hasil yang ditemukan adalah : terdapat dua famili kupu-kupu yang mengunjungi bunga . paludosa, H. rosa-chinensis dan $C$. japonicum yakni Pieridae dan Papilionidae. Kupu-kupu yang mengunjungi I. paludosa sebanyak 6 spesies, yang mengunjungi $H$. rosa-chinensis sebanyak 4 spesies dan mengunjungi $C$. japonicum sebanyak 7 spesies. Spesies kupu-kupu yang dominan mengunjungi I. paludosa adalah : Graphium agamemnon dan Catopsilia scylla. Spesies kupu-kupu yang dominan pada $H$. rosa-chinensis adalah Papilio demolion dan Troides helena, sedangkan yang sering berkunjung pada $C$. japonicum adalah : C. pomona dan C. scylla.
\end{abstract}

Kata kunci : kupu-kupu, nektar, serangga penyerbuk, Bantimurung, Sulawesi 


\section{PENDAHULUAN}

Taman Nasional BantimurungBulusaraung adalah hamparan pegunungan karst yang membentang dari Kabupaten Maros sampai Kabupaten Pangkep. Daerah ini terkenal sebagai kawasan konservasi dengan keanekaragaman kupu-kupu yang tinggi. Selain berupa hamparan pegunungan karst, di dataran yang lebih rendah terdapat hamparan sawah dan pemukiman penduduk.

Adanya perbedaan habitat di Taman Nasional Bantimurung-Bulusaraung dan sekitarnya menentukan komposisi tumbuhan yang berada di dalamnya karena berfungsi sebagai tempat berlindung, sumber makanan (nektar/pollen) dan menstabilkan kondisi iklim mikro yang sesuai untuk perkembangan serangga. Selain lebah madu, kupu-kupu merupakan serangga penyerbuk yang perlu dipertimbangkan keberadaannya di kawasan Taman Nasional Bantimurung-Bulusaraung. Kupu-kupu merupakan indikator penting dalam menentukan kualitas lingkungan karena serangga ini sangat peka terhadap polusi lingkungan. Umumnya serangga penyerbuk berasal dari ordo Lepidoptera, Hymenoptera, Diptera dan Coleoptera (Kalshoven, 1981 dan Peggie, 2011). Lee dan Heimpel (2002) melaporkan bahwa nektar yang dihasilkan oleh tumbuhan Fagopyrum esculentum (Polygonaceae) yang mekar saat pagi hari jumlahnya melimpah bila dibandingkan dengan sore hari. Nektar tersebut dimanfaatkan oleh serangga penyerbuk yakni lebah madu dan kupu-kupu.

Selain untuk mendapatkan nektar, serangga penyerbuk juga mengunjungi bunga untuk mendapatkan pollen. Umumnya serangga penyerbuk memilih bunga berdasarkan morfologi bunga yang menunjukkan kemudahan mendapatkan nektar tersebut (Landis et al., 2000 dan Wackers et al., 2007). Vandekerkhove dan de Clerqc (2010) melaporkan bahwa selain nektar, pollen atau tepung sari juga dapat meningkatkan lama hidup dan keperidian serangga predator yakni Macrolophus pygmaeus yang memakan kutu tanaman.

Pengelolaan habitat yang berada di sekitar Taman Nasional BantimurungBulusaraung sangat penting dilakukan untuk menunjang konservasi kupu-kupu yang bermukim di dalamnya. Berdasarkan hasil observasi sebelumnya, beberapa spesies kupukupu ditemukan mengunjungi pekarangan rumah penduduk yang bermukim di sekitar Taman Nasional Bantimurung-Bulusaraung. Tujuan penelitian adalah : mengidentifikasi spesies dan frekuensi kunjungan kupu-kupu pada tiga jenis bunga yakni : asoka (Ixora paludosa), kembang sepatu (Hibiscus rosachinensis) dan kembang pagoda (Clerodendron japonicum). Informasi ini sangat berguna dalam konservasi serangga penyerbuk khususnya kupu-kupu yang bermukim di sekitar Taman Nasional Bantimurung-Bulusaraung Kabupaten Maros, Sulawesi Selatan..

\section{METODE PENELITIAN}

Kegiatan penelitian berupa percobaan lapangan bertempat di Desa Simbang $\left(5^{\circ} 01^{\prime} 23.2^{\prime \prime S}\right.$ dan $\left.119^{\circ} 40^{\prime} 33.6^{\prime \prime E}\right)$ Kecamatan Bantimurung Kabupaten Maros, Sulawesi Selatan dilaksanakan pada bulan Agustus sampai dengan September 2018. Sekitar tempat percobaan merupakan kawasan konservasi Taman Nasional BantimurungBulusaraung yang banyak ditumbuhi pohon jati (Tectona grandis) dan bitti (Vitex cofassus).

Tiga jenis tanaman bunga penghasil nektar dipilih untuk mengetahui spesies kupukupu yang datang berkunjung yakni : asoka (Ixora paludosa), kembang sepatu (Hibiscus rosa-chinensis) dan kembang pagoda (Clerodendron japonicum). Di dalam lahan kosong berukuran $4 \mathrm{~m} \times 3 \mathrm{~m}$ bebas dari gulma berbunga disimpan 20 pot bunga asoka 
(dengan total kuntum bunga lebih dari 50 buah). Pengamatan spesies kupu-kupu yang datang mengunjungi bunga dilakukan selama 4 jam antara pukul $08.00-12.00$ dalam kondisi cuaca cerah. Pengamatan kunjungan kupu-kupu pada bunga asoka dilakukan selama 5 hari. Setelah selesai pengamatan dengan bunga asoka dilakukan pengamatan menggunakan kembang sepatu dan kembang pagoda dengan prosedur yang sama. Parameter pengamatannya adalah : frekuensi kunjungan, famili dan spesies kupu-kupu yang berkunjung ke tanaman bunga yang diuji. Selama percobaan berlangsung dilakukan pengukuran suhu dan kelembaban serta faktor pendukung lainnya. Identifikasi famili dan spesies kupu-kupu menggunakan literatur Peggie dan Amir (2006) serta Peggie (2011).

\section{HASIL DAN PEMBAHASAN}

Lokasi tempat berlangsungnya penelitian terletak di ketinggian sekitar $500 \mathrm{~m}$ di atas permukaan laut (dpl), rata-rata curah hujannya berkisar 1.500 - $2.100 \mathrm{~mm} /$ tahun, suhu udara minimum dan maksimum masingmasing berkisar 23 dan $32^{\circ} \mathrm{C}$, kelembaban relatif berkisar $65-88 \%$ dengan $\mathrm{pH}$ tanah berkisar 3,50 - 5,47.

Selama percobaan berlangsung terdapat dua famili kupu-kupu yang mengunjungi bunga asoka, kembang sepatu dan kembang pagoda yakni Pieridae dan Papilionidae. Jumlah spesies kupu-kupu yang mengunjungi tanaman tersebut masing-masing berturutturut : 6, 4 dan 7 spesies (Tabel 1).

Tabel 1. Kunjungan kupu-kupu terhadap tiga jenis tanaman penghasil bunga

\begin{tabular}{ll}
\hline \multicolumn{1}{c}{ Kupu-kupu Pengunjung } \\
\hline Pieridae & \multicolumn{1}{c}{ Spesies } \\
& Catopsilia Scylla \\
Papilionidae & Pomona \\
& Papilio demolion \\
& P. demoleus \\
& Troides Helena \\
& T. haliphron \\
& Graphium agamemnon \\
& Jumlah Spesies Kupu-kupu \\
\hline
\end{tabular}

Hasil pengamatan kunjungan kupukupu selama 4 jam pada tiga jenis bunga yang diuji menunjukkan bahwa kunjungan tertinggi pada bunga asoka dilakukan oleh kupu-kupu G. agamemnon (27,1 kali) dan Catopsylla scylla (12,1 kali), selanjutnya pada kembang sepatu kunjungan kupu-kupu tertinggi adalah Papilio demolion (4,4 kali) dan Troides helena (1,3 kali), pada kembang pagoda adalah Catopsilia pomona $(5,7$ kali) dan C. scylla (2,2 kali). Dapat dilihat bahwa terdapat variasi kunjungan kupu-kupu ke bunga yang diuji. Diduga bahwa variasi ini terjadi karena
Frekuensi Kunjungan

Asoka Kembang sepatu Kembang pagoda

$\begin{array}{lll}12.1 & 0 & 2.2\end{array}$

$\begin{array}{lll}3.5 & 0 & 5.7\end{array}$

$\begin{array}{lll}0 & 4.4 & 0.2\end{array}$

$\begin{array}{lll}3.7 & 1.1 & 0.3\end{array}$

$\begin{array}{lll}2.2 & 1.3 & 1.2\end{array}$

$\begin{array}{lll}10.3 & 0 & 2\end{array}$

$\begin{array}{lll}27.1 & 0.4 & 1.3\end{array}$

$6 \quad 4 \quad 7$

kandungan nektar pada bunga dan karakter morfologi bunga yang menunjukkan kemudahan serangga untuk mendapatkan nektar yang dicarinya. Hasil penelitian Lundgren (2009) dan Pohl et al., (2011) menunjukkan kecenderungan serangga memilih bunga berdasarkan kandungan nektar dan bau yang dikeluarkannya. Nektar bunga mempunyai manfaat yang sangat besar untuk serangga yang mengkonsumsinya karena dapat meningkatkan lama hidup dan kemampuan bertelur khusus untuk serangga betina. 
Secara umum kupu-kupu menyukai datang ke bunga yang berwarna cerah yakni: merah, oranye dan merah muda, sedangkan warna putih kurang disukai. Mata majemuk kupu-kupu yang terdiri dari ribuan ommatidium memiliki kemampuan membedakan warna bunga. Pohl et al. (2011) mengemukakan bahwa preferensi kupu-kupu terhadap warna bunga berlangsung secara spontan dan sangat tergantung pada bau yang dikeluarkan oleh bunga. Secara mendasar, kupu-kupu juga menyukai warna kuning, biru dan ungu. Kupu-kupu mampu belajar secara cepat berdasarkan kunjungannya ke bunga untuk mengasosiasikan warna bunga dengan kandungan nektar yang diinginkannya.

Selain mengggunakan organ penglihatan dalam mencari makanan, kupukupu juga mengandalkan organ penciuman dan peraba melalui antenna, alat mulut dan tungkainya. Kupu-kupu mengisap nektar bunga dengan bantuan proboscisnya. Viskositas dan konsentrasi gula yang terkandung di dalam nektar sangat berpengaruh dalam kemudahan mendapatkan nektar tersebut. Selain nektar yang berasal dari bunga, terdapat pula nektar ekstraflora (cairan mengandung gula berasal dari bagian tanaman selain bunga) merupakan sumber makanan yang penting untuk serangga penyerbuk. Pohl et al.(2011), melaporkan bahwa kupu-kupu famili Pieridae hanya dapat bertahan hidup selama $1-2$ hari dengan mengkonsumsi air, tetapi lama hidupnya menjadi 7 hari jika memakan nektar yang berasal dari bunga gulma Borago officinalis

Karise et. al. (2006) dan Lundgren (2009) melaporkan bahwa konsentrasi nektar bunga sangat tergantung pada spesies, musim dan kesehatan tanaman. Umumnya nektar bunga lebih kental saat musim panas. Schellhorn dan Silberbauer (2002) melaporkan bahwa produksi nektar tumbuhan Tropaeolum majus, Tagetes patula dan Alcea rosea menunjukkan bahwa spesies tersebut menghasilkan laju sekresi nektar yang tinggi.
Perlu dipahami bahwa setiap serangga akan mendapatkan nektar dengan jumlah yang berbeda tergantung ketersediaannya pada bunga.

Tumbuhan bunga penghasil nektar dan pollen merupakan sumber daya utama dalam menunjang kehidupan serangga penyerbuk yang bermukim di Taman Nasional Bantimurung-Bulusaraung. Hasil penelitian Soejono (2006) dan Barberi et al. (2010) melaporkan gulma berbunga Ageratum conyzoides yang banyak tumbuh di sekitar lahan pertanian, nektarnya menjadi sumber makanan untuk kupu-kupu serta serangga musuh alami yakni Coccinella arquata (Coleoptera: Coccinellidae) dan kepik predator Cytorrhynus lividipennis. Kedua serangga ini merupakan predator serangga hama yang merusak tanaman padi.

\section{KESIMPULAN DAN SARAN}

Temuan yang didapatkan selama penelitian adalah kupu-kupu yang mengunjungi bunga asoka sebanyak 6 spesies, yang mengunjungi kembang sepatu sebanyak 4 spesies dan mengunjungi kembang pagoda sebanyak 7 spesies. Spesies kupu-kupu yang dominan mengunjungi bunga asoka adalah: Graphium agamemnon dan Catopsilia scylla. Spesies kupu-kupu yang dominan pada kembang sepatu adalah Papilio demolion dan Troides helena, sedangkan yang sering berkunjung pada kembang pagoda adalah : $C$. pomona dan C. scylla.

\section{DAFTAR PUSTAKA}

Barberi, P., Burgio, G., Dinelli, G., Moonen. A. C., Otto, S., Vazzana, C., and Zanin, G., 2010. Functional biodiversity in the agricultural landscape: relationships between weeds and arthropods fauna. Weed Research, 50: 388-401. 
Kalshoven, L. G. E., 1981. The Pests of Crops in Indonesia. Translated and Revised by P.A. van der Laan. PT. Ichtian Baru-van Hoeve, Jakarta. 701 p.

Karise R, M. Mand, M. Ivask, E. Koskor and E. Bender, 2006. The effect of pollen amount on and its caloric value in hybrid Lucerne (Medicago x varia) on its attractiveness to bumble bees (Bombus terrestris). Agronomy Research, 4:211-216 (diakses tanggal 3 Oktober 2019).

Landis, D.A, Wratten, S. D., and Gurr, G. M., 2000. Habitat management to conserve natural enemies of arthropod pests in agriculture. Annual Review Entomology, 45:175-201.

Lee, J. C., and Heimpel, G. E., 2002. Nectar Availability and Parasitoid Sugar Feeding. The Proceeding The $1^{\text {st }}$ International Symposium on Biological Control of Arthropods. 1418 March, 2002, Honolulu Hawai USA. pp 220-225.

Lundgren, J. G., 2009. Relationship of Natural Enemies and Non-Prey Foods. Published by Springer Science USA. $434 \mathrm{p}$.

Peggie, D., and Amir, M., 2006. Practical Guide to The Butterflies of Bogor Botanical Garden. Puslit Biologi LIPI and Nagao Natural Environment Foundation.126p.

Peggie, D., 2011. Precious and Protected Indonesian Butterfly. Puslit Biologi
LIPI and Nagao Natural Environment Foundation.72p.

Pohl, N. B., van Wyk, J., and Campbell, D. R., 2011. Butterflies show flower colour preferences but not constancy in foraging at four plant species. Ecological Entomology, 360: 290 300.

Schellhorn NA and L. Silberbauer, 2002. The Role of Surrounding Vegetation and Refuges : Increasing the Effectiveness of Predators and Parasitoids in Cotton and Broccoli Systems. Proceeding The $1^{\text {st }}$ International Symposium on Biological Control of Arthropods. 1418 March, 2002, Honolulu Hawai USA. pp 235-243.

Soejono, A. T., 2006. Gulma dalam Agroekosistem : Peranan, Masalah dan Pengelolaannya. Pidato Pengukuhan Jabatan Guru Besar pada Fakultas Pertanian UGM Yogyakarta, 5 Juni 2006. 21 hal.

Wackers, F. L., Romeis, J., and van Rijn, P., 2007. Nectar and pollen feeding by insect herbivores and implications for multitrophic interactions. Апnи. Rev. Entomol., 52: 301-323 (diakses tanggal 3 Oktober 2019).

Vandekerkhove, B., and de Clerq, P., 2010. Pollen as an alternative or supplementary food for the Mirid Predator Macrolophus pygmaeus. Biological Control, 53(2): 238-242. 